\title{
Correction to: On the Use of X-ray Computed Tomography in Assessment of 3D-Printed Components
}

\author{
Mohammad Reza Khosravani $^{1}$ (D) Tamara Reinicke ${ }^{1}$
}

Published online: 17 November 2021

(c) The Author(s) 2021

\section{Correction to: \\ Journal of Nondestructive Evaluation (2020) 39:75 https://doi.org/10.1007/s10921-020-00721-1}

The article "On the Use of X-ray Computed Tomography in Assessment of 3D-Printed Components", written by Mohammad Reza Khosravani and Tamara Reinicke, was originally published electronically on the publisher's internet portal on 28 September 2020 without open access. With the author(s)' decision to opt for Open Choice the copyright of the article changed on 20 July 2021 to OThe Author(s) 2021 and the article is forthwith distributed under a Creative Commons Attribution 4.0 International License, which permits use, sharing, adaptation, distribution and reproduction in any medium or format, as long as you give appropriate credit to the original author(s) and the source, provide a link to the Creative Commons licence, and indicate if changes were made. The images or other third party material in this article are included in the article's Creative Commons licence, unless indicated otherwise in a credit line to the material. If material is not included in the article's Creative Commons licence and your intended use is not permitted by statutory regulation or exceeds the permitted use, you will need to obtain permission directly from the copyright holder. To view a copy of this licence, visit http://creativecommons.org/licenses/by/4. 0 .

Open Access This article is licensed under a Creative Commons Attribution 4.0 International License, which permits use, sharing, adaptation, distribution and reproduction in any medium or format, as long as you give appropriate credit to the original author(s) and the source, provide a link to the Creative Commons licence, and indicate if changes were made. The images or other third party material in this article are included in the article's Creative Commons licence, unless indicated otherwise in a credit line to the material. If material is not included in the article's Creative Commons licence and your intended use is not permitted by statutory regulation or exceeds the permitted use, you will need to obtain permission directly from the copyright holder. To view a copy of this licence, visit http://creativecomm ons.org/licenses/by/4.0/.

Publisher's Note Springer Nature remains neutral with regard to jurisdictional claims in published maps and institutional affiliations.

The original article can be found online at https://doi.org/10.1007/ s10921-020-00721-1.

\footnotetext{
Mohammad Reza Khosravani

mohammadreza.khosravani@uni-siegen.de

1 Institute of Product Development, University of Siegen, Paul-Bonatz-Str. 9-11, 57068 Siegen, Germany
} 